\title{
Efficient Generation of Human IgG1 Light Kappa Constant Region Knock-in Mouse by CRISPR/Cas9 System
}

\author{
Sundo Jung ${ }^{\dagger, *}$ \\ Department of Biomedical Laboratory Science, Shinhan University, Gyeonggi-do 11644, Korea
}

\begin{abstract}
Mice with specific modified genes are useful means of studying development and disease. The CRISPR/Cas9 system is a very powerful and effective tool for generating genetically modified mice in a simple and fast manner. To generate human IgG light kappa constant knock-in mice, we tested by microinjection of a mixture of Cas9 protein, single-guide RNA and target homologous recombinant donor DNA into zygotes. We found that the injection of $10 \mathrm{ng} / \mu \mathrm{L}$ of Cas9 protein and crRNA/tracrRNA, rather than single guide RNA, induced the production of knock-in mice more effectively. Thus, our study provides valuable information that will help to improve the production of knock-in mice and contribute the successful generation of humanized Ab-producing mice in Korea.
\end{abstract}

Key Words: CRISPR/Cas9 system, Knock-In mouse, Human IgG light kappa constant region, Gene editing

\section{서 론}

마우스는 포유류 모델 동물로 유전자 변형을 통해 유 전자의 기능을 이해하고 질병 치료 연구에 광범위하게 사용되고 있다. 기존에 사용되었던 유전자 변형 방법은 마우스 배아 줄기(ES) 세포에서 상동 재조합을 이용한 방 법으로 비용이 많이 들고 오랜 시간과 많은 노동이 필요 했다. 하지만 Zinc-finger nucleases (ZFNs)와 transcription activator-like effector nucleases (TALENs)와 같은 site-specific nuclease, 즉 인공 유전자 가위가 개발됨으로써 특정 유전 자 위치에서 DNA의 이중 가닥을 자르고 편집할 수 있게 되었으며 이는 유전공학에 중요한 발전을 이끌게 되었다 (Bibikova et al., 2003; Carlson et al., 2012; Cho et al., 2013). 유 전자 가위 중 가장 최근에 밝혀진 clustered regularly interspaced short palindromic repeat (CRISPR) / CRISPR-associated protein 9 (Cas9) system은 세균과 고세균 내에 존재하는 적 응 면역 시스템에서 유래한 것으로 RNA를 기반으로 작용 한다(Doudna and Charpentier, 2014). Plasmid DNA나 virus와 같은 외부 DNA가 세균에 침입했을 때 이들 DNA 서열의 일부를 기억하고 반복 감염 시 CRISPR RNAs (crRNA)와 transactivating crRNA (tracrRNA)가 형성된다. 합성된 crRNA, tracrRNA와 Cas9 단백질 복합체가 형성되며 외부 DNA 서열을 특이적으로 절단함으로써 외래 $\mathrm{DNA}$ 를 제거한다 (Hsu et al., 2013; Ran et al., 2013). Cas9 nuclease는 Streptococcus pyogenes에서 유래한 단백질로 crRNA의 spacer에 해당하는 $20 \mathrm{bp}$ 염기서열 바로 뒤에 존재하는 protospacer adjacent motif (PAM) 염기서열 5'-NGG-3'을 인식하여 PAM 서열 바로 앞을 절단하여 외래 DNA를 제거한다. 따라서 CRISPR/Cas9 system을 이용한 유전자 편집을 위해서는 Cas9 단백질과 편집하고자 하는 부위의 crRNA와 tracrRNA 가 필요하며, $\mathrm{crRNA}$ 와 tracrRNA의 필수적인 부분을 연결

Received: November 12, 2019 / Revised: December 11, 2019 / Accepted: December 20, 2019

* Professor.

${ }^{\dagger}$ Corresponding author: Sundo Jung. Department of Biomedical Laboratory Science, Shinhan University, 95, Hoam-ro, Uijeongbu-si, Gyeonggi-do 11644, Korea.

Tel: +82-31-870-3714, Fax: +82-31-870-3719, e-mail: jungsd93@shinhan.ac.kr

(C) The Korean Society for Biomedical Laboratory Sciences. All rights reserved.

(c) This is an Open Access article distributed under the terms of the Creative Commons Attribution Non-Commercial License (http://creativecommons.org/licenses/by-nc/3.0/) which permits unrestricted non-commercial use, distribution, and reproduction in any medium, provided the original work is properly cited. 
Table 1. Sequence of crRNA, tracrRNA, sgRNA oligomer used in this study

\begin{tabular}{lc}
\hline \hline \multicolumn{1}{c}{ Oligo } & Sequence \\
\hline Kappa F1 crRNA & 5'-GGUGGGAAGAUGGAUACAGUGUUUUAGAGCUAUGCUGUUUUG-3' \\
Kappa B1 crRNA & 5'-CCAUUGUCAAGAGCUUCAACGUUUUAGAGCUAUGCUGUUUUG-3' \\
tracrRNA & 5'-AAACAGCAUAGCAAGUUAAAAUAAGGCUAGUCCGUUAUCAACUUGAAAAAGUGGCAC \\
Kappa F1 & CGAGUCGGUGCU-3' \\
Kappa B1 & 5'-TAGGGGTGGGAAGATGGATACAGT-3' \\
\hline
\end{tabular}

하여 하나의 single guide RNA (sgRNA) 형태로 제공할 수 있다(Horii et al., 2014). 이와 같이 CRISPR/Cas9 system은 작 은 염기쌍 가이드 RNA (sgRNA)와 $\mathrm{Cag} 9$ 단백질을 사용하 여 외래 DNA를 부위-특이적인 방식으로 표적화하고 절 단하는 방법으로 쉽고 빠르기 때문에 많은 연구자들이 이 기술에 주목하고 이용하고 있다. 더욱이 한 개의 염기서 열을 치환하는 방법과 한 번에 여러 유전자에 돌연변이가 생성된 생쥐의 제작도 가능하게 되었다(Wang et al., 2013; Aida., 2016; Ma et al., 2017).

항체는 종종 면역글로불린으로 불리며 항원과 결합하 여 항원의 작용을 방해하거나, 항원을 제거하는 면역 단 백질이다. 항체에는 immunoglobulin(Ig)G, $\operatorname{IgM}, \operatorname{IgA}, \operatorname{IgE}$ 및 $\mathrm{IgD}$ 의 5 종류가 있다. 이들 모두는 기본적으로 4 개의 사슬 로 된 항체 구조를 갖지만, 각각 중쇄 불변영역 유전자 $\mu, \delta, \gamma, \alpha, \varepsilon$ 로부터 만들어진 중쇄를 포함한다(Lonberg and Huszar, 1995; Beck et al., 2010). 사람의 혈청 내 주된 항체 는 $\mathrm{IgG}$ 이며 구조와 기능면에서 가장 잘 알려져 있고, $\mathrm{IgG}$ 는 다시 $\mathrm{IgG} 1, \mathrm{IgG} 2, \mathrm{IgG} 3, \mathrm{IgG} 4$ isotype로 나뉘며 각각의 구조 및 기능적 특성은 다르다. $\mathrm{IgG}$ 는 중쇄(heavy chain, $50 \mathrm{kDa}$ ) 단백질 2개와 경쇄(light chain, $25 \mathrm{kDa}$ ) 단백질 2개 로 만들어진 $\mathrm{Y}$ 자 모양의 매우 안정된 구조(분자량, 150 $\mathrm{kDa}$ )을 형성하고 있다. 사람과 생쥐의 항체 유전자는 구조 적, 기능적으로 매우 유사함이 밝혀져 있다(Lonberg and Huszar, 1995).

본 연구에서는 CRISPR-Cas9 system을 이용하여 인간과 기능적으로 유사한 항체로 알려진 mouse $\mathrm{IgG} 2 \mathrm{a}$ 자리에 human IgG1의 light kappa constant 부위를 삽입시킨 마우 스(hIgG Lc KI mice)를 제작하고자 하였다. CRIRPR-Cas9 system은 많은 연구자들이 연구에 이용하고 있으나 아직 개발 초기 단계로 많은 시행 착오와 확립된 protocol이 존 재하고 있지 않다. 본 연구에서는 CRISPR/Cas9 system을 이용한 유전자 삽입(knock-in) 동물 생산에 효과적인 방법
을 제시하고, 향후 인간 항체를 생산할 수 있는 마우스 생 산을 위한 기초를 마련하고자 하였다.

\section{재료 및 방법}

\section{Mouse human IgG1 hybrid light kappa constant chain DNA 제작}

미국국립생물정보센터(NCBI)에서 human IgG1 항체 유 전자의 light kappa chain 염기서열을 확인(NC_000002.12)하 였으며, 마우스 IgG2a light kappa chain 서열(NC_000072.6) 을 비교 분석하였다. 약 $320 \mathrm{bp}$ 의 kappa constant 서열을 human 서열로 대체하고 homologous recombination (HR)이 일어날 수 있도록 5' $\mathrm{HR}$ arm과 3' $\mathrm{HR}$ arm을 각 $1.25 \mathrm{~kb}$ 정 도 포함한 마우스 염기서열 (2,803 bp)을 pUC57 vector의 EcoRI 제한효소 부위를 이용하여 삽입되도록 주문 제작 하였다(Bioneer, Korea).

\section{In vitro RNA transcription}

sgRNA의 design (Table 1)과 in vitro transcription은 zhang's laboratory에서 제공하는 방법으로 실시하였다(http://www. genome-engineering.org/crispr). 각각의 guide RNA oligomer 를 annealing 한 후 pUC57-sg RNA expression vector (Life Technologies, USA)의 Bsa I 제한효소 부위에 삽입하였다. Guide RNA 서열이 형질전환된 plasmid를 sequencing을 통 해 확인하였다. 확인된 clone은 sgRNA의 in vitro transcription template로 MEGAshortscript T7 kit (Life Technologies, USA)을 이용하여 transcription 시킨 후 RNA는 MEGAclear kit (Life Technologies, Carlsbad, CA, USA)과 elution buffer 를 이용해 분리했다. 분리된 sgRNA는 NanoDrop (Thermo Scientific, USA)을 이용해 농도와 quality를 측정하였다. 


\section{Microinjection}

C57BL/6 wt과 ICR mouse(오리엔트 바이오, 한국)를 사 용하였으며, 모든 동물 실험은 고려대학교 생명공학원 계 림실험동물 자원센터에서 진행하였다. 또한 고려대학교 실험동물 윤리위원회의 승인을 받아 승인된 지침에 따라 윤리적 기준에 의거하여 시행하였다(KUIACUC-2018-25). $\mathrm{hIgG} \mathrm{Lc} \mathrm{KI}$ 마우스 제작을 위한 microinjection은 C57BL/6 4주령 암컷 마우스를 이용하였으며 7.5 unit PMSG (Prospec, Israel)를 복강 주사 후 48시간 뒤에 동량의 hCG (Prospec, Israel) 호르몬을 복강 주사하여 과배란을 유도하였다. 과 배란이 유도된 마우스는 C57BL/6 수컷 마우스와 하룻동 안 교배 후 다음 날 vaginal plug을 체크하여 교배 유무를 확인하여 Plug이 확인된 암컷 마우스의 난관에서 수정란
을 분리했다(Ittner and Gotz, 2007). 수정란의 전핵에 준비 된 target donor DNA, sgRNA, 또는 crRNA, tracrRNA, Cas9 protein mixture를 microinjection으로 주입하였다. $37^{\circ} \mathrm{C}$ 배양 기에서 수정란이 2 cell로 분화되는 것을 현미경으로 확인 한 후, 가임신 된 ICR 암컷 마우스의 난관 팽대부에 10 20 개의 수정란을 이식하였다. 3주 후 태어나는 새끼 마우 스의 숫자를 확인하고 4주 후에 꼬리의 일부를 잘라 유 전자를 분석을 실시하였다.

\section{유전자 삽입 확인을 위한 primer 선발 및 $\mathrm{PCR}$ 확인}

Human IgG1 light kappa constant 유전자가 삽입된 마우스 확인을 위해 primer를 제작하였으며(Fig. 2, Table 2), 유전자 삽입은 PCR와 유전자 서열 분석을 통해 최종 확인하였 다. 유전자 삽입 유무 확인은 microinjection에 의해 태어

\section{(A)}

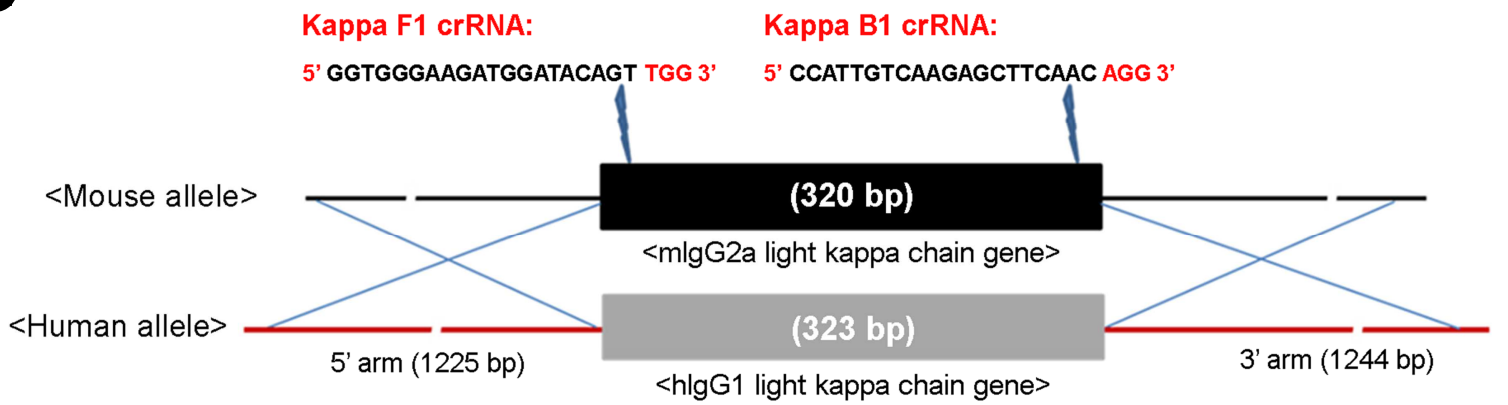

$<$ Recombinant allele $>$
$(323 \mathrm{bp})$

$3^{\prime} \operatorname{arm}(1244 \mathrm{bp})$

B

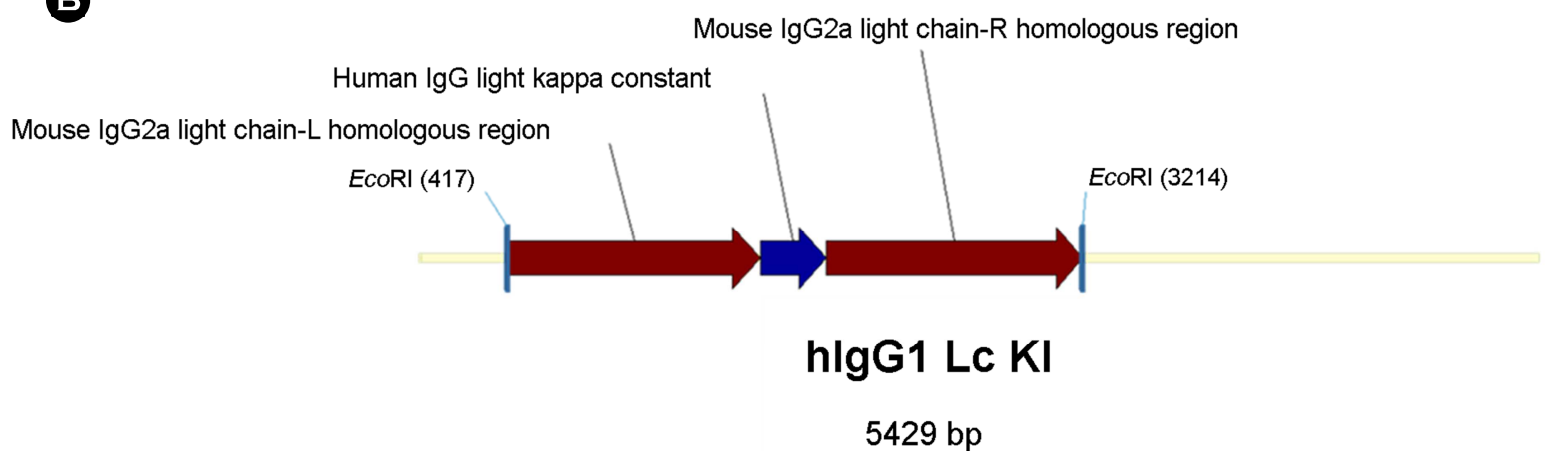

Fig. 1. Design and construction for human IgG1 light kappa Knock-In mouse. (A) In order to replace the mouse IgG1 light kappa constant gene (mIgG Lc) with the human IgG1 light kappa constant gene (hIgG Lc), Kappa F1 and Kappa B1 crRNAs were selected to recognize and cut of Cas9 protein and homologous recombination was used to increase insertion efficiency with hIgG Lc. The outer genomic DNA sequence of $\mathrm{mIgG} \mathrm{Lc}$ was inserted into the 5 'arm and the 3' arm by about $1.2 \mathrm{~Kb}$ to design a recombinant allele. (B) The designed Recombinant allele gene was used to synthesize hIgG1 Lc KI vector as donor DNA for Knock-In mouse construction. 


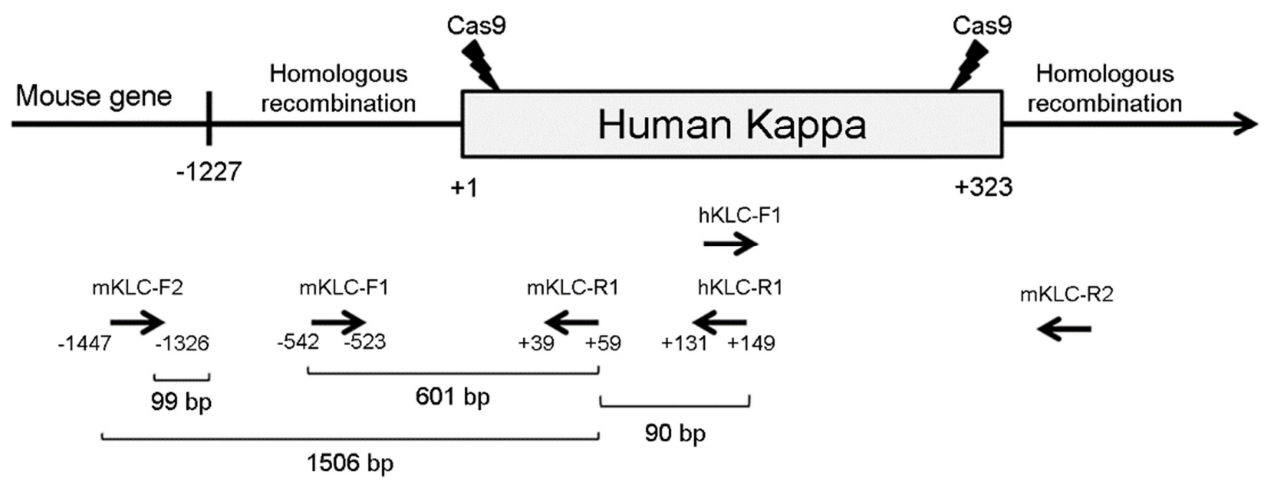

Fig. 2. Map of specific PCR primers for confirm of $\mathrm{hIgG}$ Lc KI mouse.
Table 2. Primers used in this study

\begin{tabular}{ll}
\hline \hline $\begin{array}{l}\text { Primer } \\
\text { name }\end{array}$ & \multicolumn{1}{c}{ Sequence } \\
\hline mKLC-F1 & 5'-ACC AGG GTC TGA TGA ATT GC-3' \\
mKLC-F2 & 5'-GTG CAT CCT GGC CCC ATT GTT CC-3' \\
mKLC-R1 & 5'-CC AGA TGT TAA CTG CTC ACT G-3' \\
mKLC-R2 & 5'-TGT ACT TTG AGC TCT GGA AGG C-3' \\
hKLC-F1 & 5'-G TGG AAG GTG GAT AAC GCC CT-3' \\
hKLC-R1 & 5'-T ACC CGA TTG GAG GGC GTT-3' \\
\hline
\end{tabular}

난 새끼들이 4주령이 되었을 때 실시하였으며 꼬리의 일 부를 잘라 genomic DNA를 추출하여 $\mathrm{PCR}$ 을 통해 확인했 다. PCR 조성은 AccuPower ${ }^{\circledR}$ HotStart PCR PreMix (Bioneer, Korea $)$, 각 primer $(25 \mathrm{pmol})$ 각 $1 \mu \mathrm{L}$, genomic DNA $1 \mu \mathrm{L}$ 및 $\mathrm{DW} 17 \mu \mathrm{L}$ 를 mix하여 최종 $20 \mu \mathrm{L}$ 로 실시했다, 반응 조건 은 $95^{\circ} \mathrm{C} 5$ 분, 변성 후 $95^{\circ} \mathrm{C}$ 에서 30 초, $57.5^{\circ} \mathrm{C} 30$ 초, $72^{\circ} \mathrm{C}$ 70 초를 총 30 회 반복 수행 후 $72{ }^{\circ} \mathrm{C} 5$ 분으로 실시하였으 며, PCR 산물은 $1 \%$ agarose gel에서 $100 \mathrm{v} 30$ 분 동안 전기 영동 후 결과를 확인하였다. 1 차 $\mathrm{PCR}$ 과 2차 $\mathrm{PCR}$ 을 확인 후 PCR 산물은 sequencing (Bioneer, Korea)을 통해 최종 염 기서열을 확인하여 마우스 $\mathrm{IgG} 2 \mathrm{a}$ light kappa constant 서열 이 human light kappa constant 서열로 대체된 것을 확인하 였다.

\section{유전자 발현 확인}

Human light kappa constant 유전자가 삽입된 마우스는 수 컷의 경우 6주령 이후 C57BL/6 wt female과 교배를 실시 하였으며, 암컷은 8주령 이후 수컷과 마찬가지로 C57BL/6 $\mathrm{wt}$ male과 교배를 실시하였다. 여러 차례 교배를 통해 얻 어진 마우스로부터 human $\operatorname{IgG}$ light kappa 유전자 발현을
확인하기 위해 꼬리로부터 $\mathrm{PBMC}$ 를 채취하여 FACS 염 색을 실시하였다. FACS 염색을 위해 ammonium chloridepotassium (ACK) 용액과 함께 10분간 실온에서 배양한 뒤, phosphate-buffered saline (PBS)로 세정한 다음, Fc receptor 를 발현하는 세포들에 의한 비특이적 반응을 줄이기 위해 anit-FcrRII/III mAb $(2.4 \mathrm{G} 2)$ 를 이용하여 $4{ }^{\circ} \mathrm{C}$ 에서 15 분간 반 응시켰다. 유세포 분석을 위해 FITC-conjugated anti-mouse B220 (BD Biosciences, USA), PE-conjugated anti-mouse Igk (BD Biosciences, USA), APC-conjugated anti-human Igk B220 (BD Biosciences, USA) 항체를 각각 처리하여 $4{ }^{\circ} \mathrm{C}$ 에서 30 분 간 반응하였다. 항체 반응이 끝난 세포를 $\mathrm{PBS}$ 로 세척하고, $1 \%$ paraformaldehyde $300 \mu \mathrm{L}$ 에 고정하여, 유세포 분석기 (FACSCalibur; USA)로 분석하였다. 분석 프로그램으로는 CellQuest software (BD Biosciences)를 사용하였다.

\section{결 과}

Humanized IgG1 light kappa constant region KnockIn 생쥐 제작을 위한 디자인

사람의 항체를 생산하는 마우스 제작을 위해 본 연구에 서는 마우스 IgG light kappa constant 부위를 먼저 인간의 유전자로 대체하고자 하였다. CRISPR/Cas9 system을 이용 하여 마우스 $\operatorname{IgG1}$ kappa constant region을 human $\operatorname{IgG}$ kappa constant region으로 대체 삽입된 마우스를 제작하여 향후 인간의 항체를 생산하고자 하였다. 마우스 IgG1 light kappa constant 유전자는 6번 염색체에 위치하며 320 bp (Gene ID: 16071)로 구성되어 있으며, human IgG light kappa constant region은 2번 염색체에 위치하며 $323 \mathrm{bp}$ (Gene ID: 3514)의 크기를 가지고 있다. 두 유전자는 약 $71 \%$ 정도의 상동성 을 가지고 있으며, 혈액 내 가장 풍부하며 매우 유사한 기 능을 한다. 유전자 삽입의 효율을 증가시키기 위해 mouse 
Table 3. Summary of CRISPR/Cas9 mediated Knock-In mouse

\begin{tabular}{lcccccc}
\hline \hline \multicolumn{1}{c}{ Guide RNA } & $\begin{array}{c}\text { Cas9 protein } \\
\text { conc }\end{array}$ & $\begin{array}{c}\text { Injected } \\
\text { egg }\end{array}$ & $\begin{array}{c}\text { Transferred } \\
(\%)\end{array}$ & $\begin{array}{c}\text { Newborn } \\
(\%)\end{array}$ & $\begin{array}{c}1^{\text {st }} \text { PCR targeted } \\
(\%)\end{array}$ & $\begin{array}{c}2^{\text {nd }} \text { PCR Knock-In } \\
(\%)\end{array}$ \\
\hline sgRNA & $100 \mathrm{ng} / \mu \mathrm{L}$ & 681 & $608(89.3)$ & $54(8.9)$ & $3(5.5)$ & $0(0)$ \\
sgRNA & $10 \mathrm{ng} / \mu \mathrm{L}$ & 594 & $512(86.2)$ & $50(9.8)$ & $4(8)$ & $0(0)$ \\
crRNA and tracrRNA & $100 \mathrm{ng} / \mu \mathrm{L}$ & 613 & $554(90.4)$ & $58(10.5)$ & $21(36.2)$ & $1(1.7)$ \\
crRNA and tracrRNA & $10 \mathrm{ng} / \mu \mathrm{L}$ & 718 & $679(94.6)$ & $74(10.9)$ & $27(36.5)$ & $3(4.1)$ \\
\hline
\end{tabular}

IgG1 light kappa 유전자 부위에 hIgG light kappa 유전자 서 열을 삽입하고, Fig. 1A의 recombinant allele과 같이 mouse IgG1 light kappa region 바깥쪽에 위치한 서열의 5' HR arm 과 3' $\mathrm{HR}$ arm을 약 $1.2 \mathrm{~kb}$ 씩 mouse 서열을 삽입하여 상동 재조합이 일어 날 수 있도록 설계하였다(Fig. 1A). 설계된 유전자는 humanized IgG1 light kappa chain을 발현하는 마우 스를 제작하기 위한 donor vector로 이용하고자 DNA (hIgG Lc KI vector)를 합성하였다(Fig. 1B). CRISPR/Cas9 system 을 이용한 유전자 편집 기능은 Cas9 단백질이 자를 수 있 는 PAM 서열을 가진 target guide RNA 선정이 매우 중요 하다. 3' 말단에 $\mathrm{NGG}$ 를 제외한 17 24 bp는 40 80\%의 $\mathrm{GC}$ 함량을 포함하며 또한 길이가 짧을수록 off target 효 과가 최소화되는 것으로 알려져 있다. Guide RNA 서열은 $\mathrm{RGEN}$ 과 MIT와 같은 웹에서 제공하는 서열을 참고·비교 하여 선정하였으며(Table 1), sgRNA를 위한 oligomer는 바 이오니아에서 합성하였고, crRNA와 tracrRNA는 다마콘에 서 합성하였다. Cas9 단백질이 인식해서 자르는 target 부 위는 human light kappa chain의 5' 말단(15번째)과 3' 말단 (308번째)에 위치하여 human 유전자 손실을 최소화하였 다(Fig. 1A).

\section{hlgG1 Lc Knock-In 마우스 제작을 위한 microinjection}

최근 CRISPR/Cas9 system을 이용한 gene editing은 많은 연구자들을 통해 활발하게 연구가 진행되고 있다. 하지만 형질전환 동물 생산 분야에서는 비용과 시설적인 측면에 서 접근이 쉽지 않기 때문에 매우 한정적인 연구가 진행 되고 있다. 따라서 CRISPR/Cas9 system을 이용한 효율적 인 형질전환 동물 제작 방법의 제시는 매우 중요하다. 이 번 연구에서는 CRISPR/Cas9 system을 이용하여 원하는 유 전자를 삽입하는 Knock-In 마우스를 제작할 때 효율을 증 가시키는 방법을 찾고자 하였다. Cas9 단백질(NEB, USA) 과 donor DNA (hIgG Lc KI vector)를 기본으로 이용하였으 며, target guide RNA를 sgRNA와 crRNA/ tracrRNA 형태로
이용했을 때 생산되는 KI 마우스 효율을 비교하였다. 또 한 microinjection 시에 donor DNA의 농도와 Cas9 단백질 의 농도를 $100 \mathrm{ng} / \mu \mathrm{L}, 10 \mathrm{ng} / \mu \mathrm{L}$ 의 조합으로 실시하여 비교 하였다. Donor DNA를 $100 \mathrm{ng} / \mu \mathrm{L}$ 로 고농도를 사용했을 경 우, egg transfer 후에 pup이 생성되지 않아 비교에서 제외 하였다(data not shown). KI 마우스 생산 효율 비교를 위해 먼저 Kappa F1 sgRNA $2.5 \mathrm{ng} / \mu \mathrm{L}$, Kappa B1 sgRNA $2.5 \mathrm{ng} / \mu \mathrm{L}$ 와 Cas9 단백질 $100 \mathrm{ng} / \mu \mathrm{L}$ 또는 $10 \mathrm{ng} / \mu \mathrm{L}, 10 \mathrm{ng} / \mu \mathrm{L}$ donor $\mathrm{DNA}$ 를 수정란의 전핵에 microinjection으로 주입하였다. 다음으로는 Kappa F1 crRNA 0.6 pmol/ $\mu \mathrm{L}$, Kappa B1 crRNA $0.6 \mathrm{pmol} / \mu \mathrm{L}$, tracrRNA $0.6 \mathrm{pmol} / \mu \mathrm{L}$ 와 Cas9 단백질 $100 \mathrm{ng} /$ $\mu \mathrm{L}$ 또는 $10 \mathrm{ng} / \mu \mathrm{L}, 10 \mathrm{ng} / \mu \mathrm{L}$ donor DNA를 수정란의 전핵에 microinjection을 실시했다. sgRNA를 주입한 후 전체 104 마리의 새끼가 태어났으며, crRNA와 tracrRNA을 주입한 경우에는 전체 132마리의 새끼를 얻을 수 있었다(Table 3). Target guide RNA의 차이인 sgRNA나 crRNA/tracrRNA 를 사용했을 때, 수정란을 대리모에 이식 후 새끼를 얻을 때까지는(Transfer 효율: $87.8 \%$ vs. $92.5 \%, P=0.08$, newborn 효율: $9.4 \%$ vs. $10.5 \%, P=0.06)$ 큰 차이를 보이지 않았다 (Table 3).

\section{hlgG1 Lc Knock-In 마우스 확인}

sgRNA 주입과 crRNA/tracrRNA 주입을 통해 얻어진 새 끼들로부터 human IgG1 light kappa constant 유전자의 삽입 을 확인하기 위해 4주령이 될 때까지 기다린 후 꼬리의 일부를 잘라 genomic DNA를 추출하였다. 먼저 1차 PCR 로 mKLC-F1과 hKLC-R1 primer를 이용하여 human IgG light kappa chain의 삽입을 확인하였다(690 bp PCR 산물). 1 차 PCR 결과 $\operatorname{sgRNA}$ 를 주입한 후 얻어진 104마리의 새 끼 중 Cas9 단백질을 $100 \mathrm{ng} / \mu \mathrm{L}$ 를 사용했을 때 3마리, Cas9 단백질을 $10 \mathrm{ng} / \mu \mathrm{L}$ 를 사용했을 때 4마리에서 유전자 삽입 이 확인되었다. 또한 crRNA/tracrRNA와 $100 \mathrm{ng} / \mu \mathrm{L}$ 의 Cas9 단백질을 주입한 후 얻어진 58 마리 새끼 중 21 마리가 1 차 
(A)
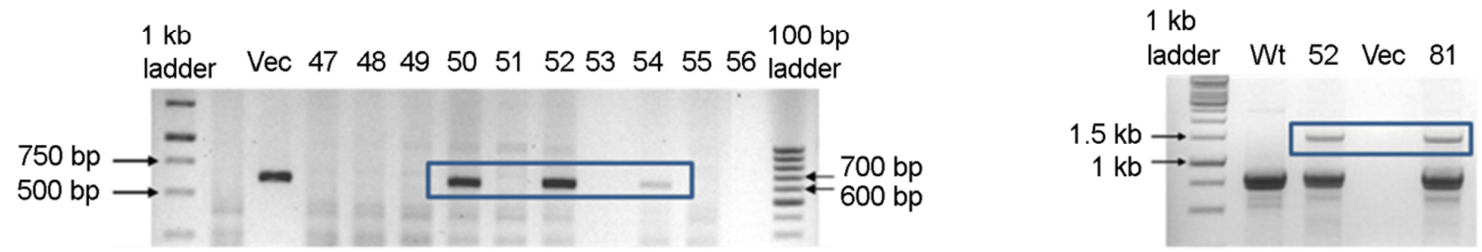

B
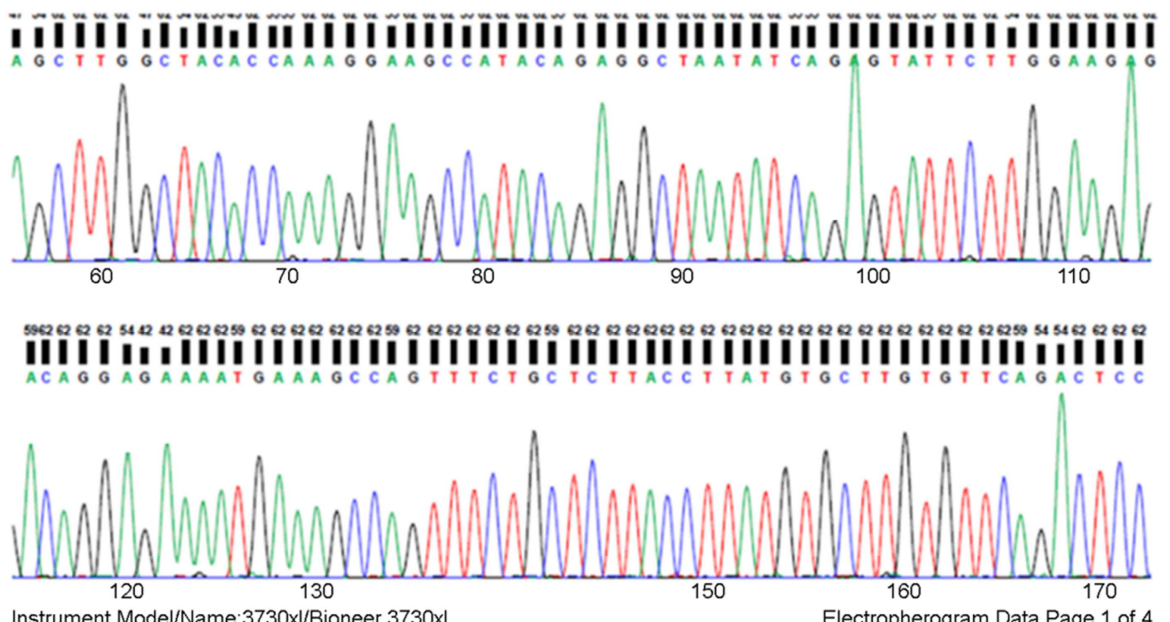

Instrument Model/Name:3730x//Bioneer 3730x|

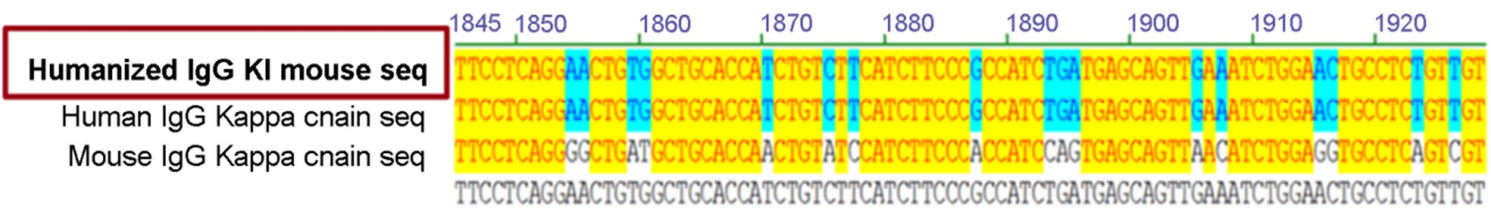

Fig. 3. Analysis of hIgG Lc KI mice. (A) Mice born through the CRISPR / Cas9 system cut off a portion of the tail at 4 weeks of age and confirmed the gene KI by PCR. In the first PCR, human gene insertion (690 bp) was confirmed using mKLC-F1 and hKLC-R1 primers. In the first PCR, the mice inserted into the gene were confirmed to be inserted $(1.6 \mathrm{~Kb})$ at the desired position by the second PCR (mKLC-F2 and mKLC-R1 primers). (B) Mouse confirmed by the secondary PCR confirmed that the normal gene (humanized IgG KI) is inserted through sequencing.

$\mathrm{PCR}$ 에서 유전자 삽입이 확인되었으며, $10 \mathrm{ng} / \mu \mathrm{L} \mathrm{Cas} 9$ 단백 질과 crRNA 조합을 사용했을 때는 전체 74마리 중 27마 리가 1차 PCR에서 유전자 삽입이 확인되었다(Fig. 3A). 1 차 PCR에서 확인된 54마리 중 정확한 위치에 삽입되었는 지 확인을 위해 2차 PCR을 mKLC-F2과 mKLC-R1 primer 를 이용하여 확인하였다(Fig. 3A). 삽입된 서열에 mutation 이 없는지 염기서열 확인을 위해 mKLC-F2과 hKLC-R1 primer와 hKLC-F1과 mKLC-R2 primer를 이용하여 PCR을 실시한 후 염기서열 분석을 실시하였다. 2 차 $\mathrm{PCR}$ 결과 $\operatorname{sgRNA}$ 를 주입한 후 얻은 7 마리에서는 원하는 위치에 유
전자 삽입을 확인할 수 없었으며, crRNA/tracrRNA와 100 $\mathrm{ng} / \mu \mathrm{L}$ Cas9 단백질 주입을 통해 얻은 21마리 중 1 마리와 crRNA/tracrRNA와 $10 \mathrm{ng} / \mathrm{\mu L}$ Cas9 단백질 주입을 통해 얻 은 27리 중 3마리에서 유전자 삽입을 확인(1.6 kb)하였으 며, 염기서열 분석을 통해 정상적인 유전자임을 확인하였 다(Fig. 3B).

\section{Human IgG light kappa chain 유전자 발현 확인}

Fig. 3에서와 같이 $1 \cdot 2$ 차 $\mathrm{PCR}$ 과 염기서열 분석을 통해 human $\mathrm{IgG}$ light kappa constant 유전자가 삽입된 것을 확인 


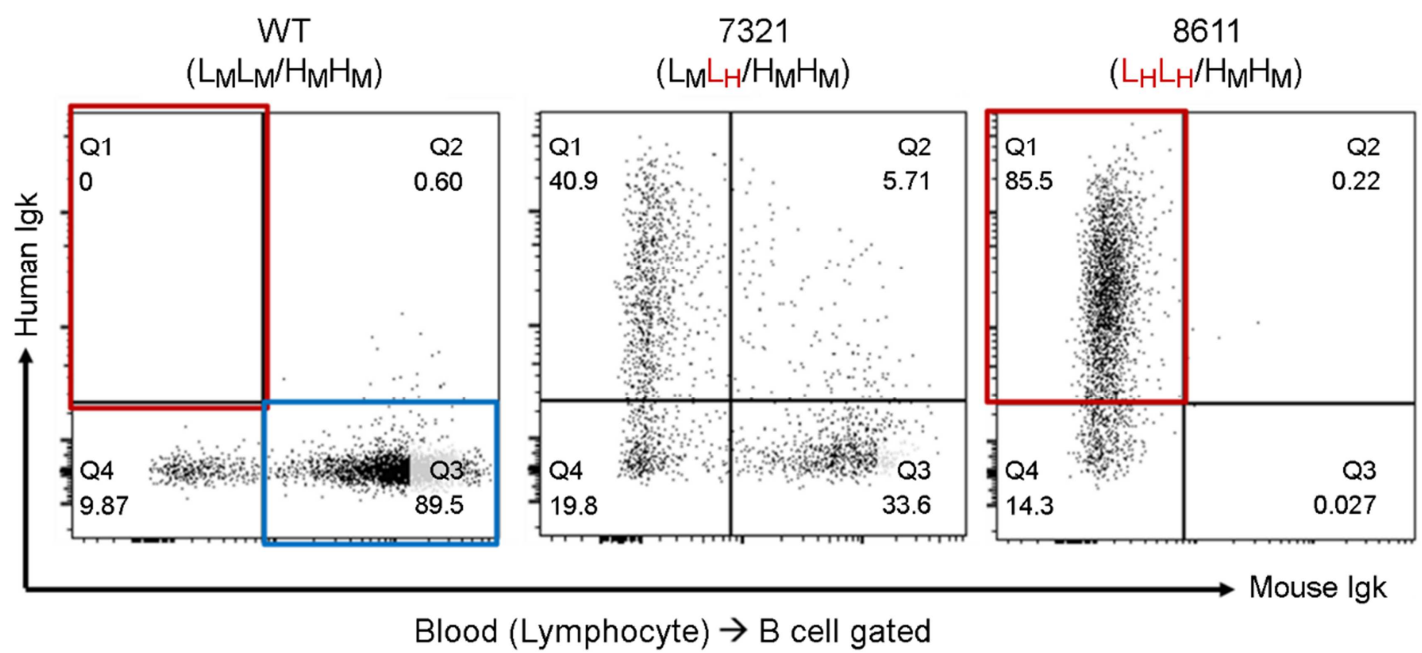

Fig. 4. Human IgG light kappa chain is expressed in B cells of hIgG Lc KI mice. Human IgG light kappa constant gene expression was confirmed from KI mice inserted with hIgG Lc gene. PBMCs of wild type mice and hIgG Lc KI mice were stained with mB220, $\mathrm{mIgK}$ and hIgk antibodies, and the expression of mouse IgG kappa chain and human IgG kappa chain among B cells was confirmed through FACS analysis.

하였다. 다음으로는 human IgG light kappa constant 유전자 발현을 확인하였다. 유전자의 삽입이 일어나더라도 발현 이 되지 않는 경우에는 항체를 생산하는 마우스로서 기 능을 할 수 없기 때문에 삽입된 유전자가 마우스 생체 내에서 발현되는지를 확인하는 것이 중요하다. 이를 위해 $\mathrm{hIgG} \mathrm{Lc} \mathrm{KI}$ 마우스는 여러 차례 교배가 진행되었으며, 교배 후 얻어진 새끼의 $\mathrm{PBMC}$ 를 분리하여 $\mathrm{B}$ 세포에서 human IgG kappa chain의 발현을 FACS 염색을 통해 확인 하였다. Fig. 4와 같이 $\mathrm{hIgG} \mathrm{Lc+/-} \mathrm{(ID \# 7321)는} 33.6 \%$ 의 mouse Ig kappa chain을 발현하며 40.9\%의 human Ig kappa chain을 발현하는 반면, $\mathrm{hIgG} \mathrm{Lc+/+} \mathrm{(ID \# 8611)는} 85.5 \%$ 의 human Ig kappa chain만을 발현했다. 결과적으로 CRISPR/ Cas9 system을 통해 제작된 hIgG Lc Knock-In 마우스가 정 상적으로 인간 항체 단백질을 발현하는 것을 확인할 수 있었다.

\section{고 찰}

치료용 항체는 1994 년 첫 항체 치료제가 개발·상품화 된 이래로 가장 빠른 성장을 보이고 있는 의약품 중 하나 로 다양한 자가면역질환, 암, 급성 골수 백혈병, 건선, 골 다공증 치료에 이용되고 있다. 초기 치료제는 단백질공학 발전에 의한 재조합 단백질 항체 치료제 형태였으나, 최 근에는 인간 항체 유전자를 이식한 형질전환 마우스로부
터 항원 특이적인 인간 단일클론 항체를 제조하는 기술까 지 발전하였다(Deng and Capecchi, 1992; Green et al., 1994; Lonberg, 2008). 미국이나 일본에서는 인간 항체를 생산할 수 있는 형질전환 마우스를 이용한 치료용 항체가 현재 시판 중이거나 임상 시험단계에 있는 항체가 50 여종에 이 르고 있을 만큼 활발한 연구가 진행 중이다(Green, 1999; Lonberg, 2008). 하지만 국내에서는 형질전환 마우스 생산 기술력의 한계와 고가의 비용, 제작에 소요되는 기간, 시 설 유지 등의 문제로 인간의 항체를 생산하는 마우스에 대 한 연구가 진행되지 않고 있다. 사람의 항체를 생산하는 마우스가 제작되면 기존에 시판되지 않은 다양한 항원에 따른 항체를 생산할 수 있으며, 국외에서 보유하고 있는 humanized $\mathrm{Ab}$ 마우스와 제작 기법과 항체 유전자 디자인 의 차이로 차별성을 가지기 때문에 본 연구에서 제작하고 자 하는 human Ig KI 마우스도 충분한 경쟁력을 있을 것 으로 기대된다.

$\mathrm{Cas} 9$ 단백질과 $\mathrm{sgRNA}$ 를 사용하면 전사와 번역과정이 생략되기 때문에 빠른 시간 내에 돌연변이가 유도되고 단 시간 동안에만 유전체가 CRISPR/Cas9에 노출되어 offtarget이 줄어드는 것으로 알려져 있다(Fu et al., 2013; Shen et al., 2014). CRISPR/Cas9 system을 이용한 다양한 유전자 편집이 인간배아줄기 세포를 비롯하여 마우스, drosophila, zebrafish, rice, Arabidopsis 등 동·식물의 모델 시스템에서 활발한 연구들이 진행되고 있다(Shan et al., 2013; Fu et al., 
2013; Yan et al., 2014; Chu et al., 2015). 특히 형질전환 마우 스 제작에서 다양한 형태의 유전자 편집이 이루어지면서 CRISPR/Cas9 system의 적용 방법에 따른 정확성과 적중 효율에 대해 제시하고 있다(Horii et al., 2014; Chu et al., 2016; Raveux et al., 2017). 유전자를 제거하는 방법은 비교 적 높은 효율의 유전자 편집이 가능하며 표준화된 방법도 가능하다. 하지만 원하는 부위에 원하는 유전자를 삽입하 는 Knock-in의 경우는 CRISPR/Cas9 system이 유전자 서열 특이적으로 반응하며 target guide RNA를 선정해야 하기 때문에 편집하고자 하는 유전자 내에 디자인할 수 있는 부위가 매우 한정적인 경우 표준화 된 방법을 적용하기 어렵다. 본 연구에서는 하나의 target guide RNA를 사용 하는 경우, in vitro에서 RNA를 transcription 시킨 sgRNA 형태로 주입한 결과에서는 Cas9 단백질의 농도와 상관없 이 최종 유전자 삽입을 확인할 수 없었다(Table 3). 반면에 target guide RNA를 crRAN/tracrRNA 형태로 Cas9 단백질 과 injection한 경우, Cas9 단백질을 고농도 $(100 \mathrm{ng} / \mu \mathrm{L})$ 로 사용했을 때보다 저농도 $(10 \mathrm{ng} / \mu \mathrm{L})$ 로 사용했을 때 효과적 으로 유전자가 삽입되는(4.1\% vs. $1.7 \%)$ 것을 확인하였다. 유전자 삽입 마우스와 같은 형질전환 마우스를 제작함에 있어 중요한 요인으로 작용하는 것이 microinjection 기술 이다. 본 연구팀에서 제작했던 유전자를 과발현 시킨 형 질전환(transgenic, $\mathrm{Tg}$ ) 마우스의 microinjection 성공률은 20 50\%의 높은 $\mathrm{Tg}$ 성공률을 보였다(data not shown). 하지 만 이번 site-specific $\mathrm{hIgG} \mathrm{Lc} \mathrm{KI}$ 마우스 생산에서는 최종적 으로 $\mathrm{KI}$ 성공률이 $4.1 \%$ 에 그쳤다. 이러한 차이는 microinjection의 기술적 한계라기보다는 유전자 서열의 특성으 로 판단할 수 있다.

본 연구를 통해 제작된 $\mathrm{hIgG} \mathrm{Lc} \mathrm{KI}$ 마우스와 추후 제작 할 $\mathrm{IgG}$ heavy chain의 가변 영역을 지닌 마우스를 통해 사 람의 항체를 생산하는 마우스를 최종적으로 생산하고자 한다. 이번 연구는 향후 항체 치료제 개발 및 연구에 많은 활용 가치가 있을 것으로 기대된다.

\section{ACKNOWLEDGEMENT}

본 논문은 2019년도 신한대학교 학술연구비 지원으로 연구되었음.

\section{CONFLICT OF INTEREST}

No potential conflict of interest relevant to this article was reported.

\section{REFERENCES}

Aida T, Chiyo K, Usami T, Ishikubo H, Imahashi R, Wada Y, Tanaka KF, Sakuma T, Yamamoto T, Tanaka K. Efficient generation of Rosa26 knock-in mice using CRISPR/Cas9 in C57BL/6 zygotes. BMC Biotechnol. 2016. 16: 86-97.

Beck A, Wurch T, Bailly C, Corvaia N. Strategies and challenges for the next generation of therapeutic antibodies. Nat Rev Immunol. 2010. 10: 345-352.

Bibikova M, Beumer K, Trautman JK, Carroll D. Enhancing gene targeting with designed zinc finger nucleases. Science. 2003. 300: 764 .

Carlson DF, Tan W, Lillico SG, Stverakova D, Proudfoot C, Christian M, Voytas DF, Long CR, Whitelaw CB, Fahrenkrug SC. Efficient TALEN-mediated gene knockout in livestock. Proc Natl Acad Sci U S A. 2012. 109: 1782-1787.

Cho SW, Kim S, Kim JM, Kim JS. Targeted genome engineering in human cells with the Cas9 RNA-guided endonuclease. Nat Biotechnol. 2013. 31: 230-232.

Chu VT, Weber T, Graf R, Sommermann T, Petsch K, Sack U, Volchkov P, Rajewsky K, Kuhn, R. Efficient generation of Rosa26 knock-in mice using CRISPR/Cas9 in C57BL/6 zygotes. BMC Biotechnol. 2016. 16: 4-7.

Chu VT, Weber T, Wefers B, Wurst W, Sander S, Rajewsky K, Kuhn R. Increasing the efficiency of homology-directed repair for CRISPR-Cas9-induced precise gene editing in mammalian cells. Nat Biotechnol. 2015. 33: 543-548.

Deng C, Capecchi MR. Reexamination of gene targeting frequency as a function of the extent of homology between the targeting vector and the target locus. Mol Cell Biol. 1992. 12: 33653371.

Doudna JA, Charpentier E. Genome editing. The new frontier of genome engineering with CRISPR-Cas9. Science. 2014. 346: 1258096.

Fu Y, Foden JA, Khayter C, Maeder ML, Reyon D, Joung JK, Sander JD. High-frequency off-target mutagenesis induced by CRISPR-Cas nucleases in human cells. Nat Biotechnol. 2013. 31: 822-826.

Green LL. Antibody engineering via genetic engineering of the mouse: XenoMouse strains are a vehicle for the facile generation of therapeutic human monoclonal antibodies. J Immunol Methods. 1999. 231: 11-23.

Green LL, Hardy MC, Maynard-Currie CE, Tsuda H, Louie DM, 
Mendez MJ, Abderrahim H, Noguchi M, Smith DH, Zeng Y, David NE, Sasai H, Garza D, Brenner DG, Hales JF, McGuinness RP, Capon DJ, Klapholz S, Jakobovits A. Antigenspecific human monoclonal antibodies from mice engineered with human Ig heavy and light chain YACs. Nat Genet. 1994. 7: 13-21.

Horii T, Arai Y, Yamazaki M, Morita S, Kimura M, Itoh M, Abe Y, Hatada I. Validation of microinjection methods for generating knockout mice by CRISPR/Cas-mediated genome engineering. Sci Rep. 2014. 4: 4513-4518.

Hsu PD, Scott DA, Weinstein JA, Ran FA, Konermann S, Agarwala V, Li Y, Fine EJ, Wu X, Shalem O, Cradick TJ, Marraffini LA, Bao G, Zhang, F. DNA targeting specificity of RNA-guided Cas9 nucleases. Nat Biotechnol. 2013. 31: 827-832.

Ittner LM, Gotz J. Pronuclear injection for the production of transgenic mice. Nat Protoc. 2007. 2: 1206-1215.

Lonberg N. Fully human antibodies from transgenic mouse and phage display platforms. Curr Opin Immunol. 2008. 20: 450 -459 .

Lonberg N, Huszar D. Human antibodies from transgenic mice. Int Rev Immunol. 1995. 13: 65-93.

Ma X, Chen C, Veevers J, Zhou X, Ross RS, Feng W, Chen, J. CRISPR/Cas9-mediated gene manipulation to create singleamino-acid-substituted and floxed mice with a cloning-free method. Sci Rep. 2017. 7: 42244-42252.

Ran FA, Hsu PD, Lin CY, Gootenberg JS, Konermann S, Trevino AE, Scott DA, Inoue A, Matoba S, Zhang Y, Zhang F. Double nicking by RNA-guided CRISPR Cas9 for enhanced genome editing specificity. Cell. 2013. 145: 1380-1389.

Raveux A, Vandormael-Pournin S, Cohen-Tannoudji M. Optimization of the production of knock-in alleles by CRISPR/Cas9 microinjection into the mouse zygote. Sci Rep. 2017. 7: 42661 -42670 .

Shan Q, Wang Y, Li J, Zhang Y, Chen K, Liang Z, Zhang K, Liu J, Xi JJ, Qiu JL, Gao C. Targeted genome modification of crop plants using a CRISPR-Cas system. Nat Biotechnol. 2013. 31: 686-688.

Shen B, Zhang W, Zhang J, Zhou J, Wang J, Chen L, Wang L, Hodgkins A, Iyer V, Huang X, Skarnes WC. Efficient genome modification by CRISPR-Cas9 nickase with minimal off-target effects. Nat Methods. 2014. 11: 399-402.

Wang H, Yang H, Shivalila CS, Dawlaty MM, Cheng AW, Zhang $\mathrm{F}$, Jaenisch R. One-step generation of mice carrying mutations in multiple genes by CRISPR/Cas-mediated genome engineering. Cell. 2013. 153: 910-918.

Yan, H, Wang H, Jaenisch R. Generating genetically modified mice using CRISPR/Cas-mediated genome engineering. Nat Protoc. 2014. 9: 1956-1968.

https://doi.org/10.15616/BSL.2019.25.4.372

Cite this articrle as: Jung S. Efficient Generation of Human IgG1 Light Kappa Constant Region Knock-in Mouse by CRISPR/Cas9 System. Biomedical Science Letters. 2019. 25: 372-380. 